\title{
PARACETAMOL-INDUCED CHANGES OF HAEMATO- BIOCHEMICAL AND OXIDATIVE STRESS PARAMETERS IN RAT BLOOD: PROTECTIVE ROLE OF VITAMIN C AND $\beta$-GLUCAN
}

\author{
Miloš M. Matić ${ }^{1}$, Marija D. Milošević ${ }^{1}{ }^{*}$, Milica G. Paunović ${ }^{1}$, Branka I. Ognjanović ${ }^{1}$, \\ Andraš Š. Štajn ${ }^{1}$, Zorica S. Saičić ${ }^{2}$ \\ ${ }^{1}$ Department of Biology and Ecology, Faculty of Science, University of Kragujevac, \\ 34000 Kragujevac, Republic of Serbia \\ ${ }^{2}$ Institute for Biological Research "Siniša Stanković", University of Belgrade, \\ 11000 Belgrade, Republic of Serbia \\ *Corresponding author; E-mail: marijadm.90@gmail.com
}

(Received March 25, 2016)

\begin{abstract}
Paracetamol (acetaminophen) is widely used as an over-the-counter analgesic and antipyretic drug. The aim of this study was to investigate the possible protective effects of vitamin C (100mg/kg/day i.p.) and $\beta$-glucan $(40 \mathrm{mg} / \mathrm{kg} /$ day i.p.) on altered haematological, biochemical and oxidative stress parameters in the blood of rats treated with paracetamol (100 mg/kg/day i.p.) for 3 days. Exposure of rats to paracetamol caused changes of some haematological parameters (RBCs count, $\mathrm{Hb}$ concentration, $\mathrm{Ht}$ value and WBCs count), suggesting that the paracetamol induced haematotoxicity. Paracetamol reduced serum total protein (TP), albumin and globulin, while increased alanine aminotransferase (ALT), aspartate aminotransferase (AST) and lactate dehydrogenase $(\mathrm{LDH})$ activities compared to the control. The results indicate that paracetamol is led to significant decrease in the concentration of $\mathrm{Na}^{+}$and $\mathrm{K}^{+}$and increase of $\mathrm{Ca}^{2+}$ in the serum compared to the control. Coadministration of vitamin $\mathrm{C}$ and $\beta$-glucan with paracetamol reversed these changes of haematological and biochemical parameters and diminished the toxic effects of paracetamol. The obtained results indicated that the concentration of LPO in erythrocytes significantly increased in, while the concentration of GSH significantly decreased in the group treated with paracetamol compared to control group. Coadministration of vitamin $\mathrm{C}$ and $\beta$-glucan with paracetamol reversed paracetamol-induced alterations in these oxidative stress parameters. This study suggests that paracetamol has significant prooxidative effects and may disrupt oxidant/antioxidant balance in erythrocytes. Furthermore, coadministration with vitamin $\mathrm{C}$ and $\beta$-glucan have protective effects on paracetamol-induced oxidative damage and haematotoxicity.
\end{abstract}

Keywords: paracetamol, vitamin C $\beta$-glucan, oxidative stress, haemato-biochemical parameters, erythrocytes.

\section{INTRODUCTION}

Paracetamol is widely used in analgo-antipyretic purposes, without medical prescription, especially in childhood. When administered at normal doses, paracetamol is 
primarily metabolized by conjugation with sulfate and glucuronic acid. A minor pathway through cytochrome P450 (CYP450) has been also reported to yield a highly reactive metabolite $\mathrm{N}$-acetyl-p-benzoquinone imine (NAPQI) that covalently binds to protein (HINSON et al., 2010). This metabolite is initially detoxified by conjugation with reduced glutathione (GSH) to form mercapturic acid and eliminated via the kidney (HINSON et al., 2010). However, when overdose of paracetamol is administered, the production of NAPQI exceeds the capacity of GSH to detoxify it. The excess NAPQI then causes liver damage associated with oxidative stress (BESSEMS and VERMEULEN, 2001). Paracetamol overdose is also known to be associated with inflammation, marked by an increase in the inflammatory cytokines, as well as the upregulation of nitrogen oxide (NO) from serum, macrophages and hepatocytes (JAESCHKE et al., 2013). It has been reported that one of the mechanisms is disturbance of prooxidant-antioxidant balance in tissues, which results in increased levels of reactive oxygen species (ROS) and oxidative damage of macromolecules as reviewed by Wulf DRÖGE (2002). This can lead to various pathological conditions in humans and animals, such as hepatic and renal dysfunction, testicular damage, respiratory disorders, and cancer (HINSON et al., 2010).

On the other hand, there are numerous reports indicating that paracetamol-mediated oxidative stress or hepatotoxicity is attenuated by use of naturally occurring antioxidants and/or free radical scavengers such as vitamins, medicinal plants and natural products (SINGH et al., 2011; JAESCHKE et al., 2013).

Ascorbic acid is a cofactor for a number of metabolic enzymes and is an indisputable essential vitamin for humans. Under physiological conditions, it functions as a potent reducing agent that efficiently quenches potentially damaging free radicals produced by normal metabolic respiration of the body (WILSON, 2002). Vitamin C is considered to be an important antioxidant in extracellular fluid; it also guards against aqueous radicals in blood and protects plasma lipids from peroxidative damage caused by peroxyl radicals (BARJA et al., 1994). Furthermore, there are a few studies reporting the antioxidant power of vitamin $\mathrm{C}$ against different chemicals-induced oxidative tissue injury (CARR and FREI, 1999; ADENEYE and OlagunJu, 2008; HASSANin et al., 2013).

Beta-D-glucans belong to a group of natural, physiologically active compounds, generally called biological response modifiers. Glucans are glucose polymers found in plants, fungi and some bacterial species, and currently are well-established and powerful immunomodulators with beneficial properties in cancer therapy (HAVRLENTOVA et al., 2011). The significant role of glucans in infection immunity, stress reduction and restoration of damaged bone marrow has already been established (UsKOKOVIĆ et al., 2013).

The aim of this study was to investigate the possible protective effects of vitamin $\mathrm{C}$ and $\beta$-glucan on altered haematological, biochemical and oxidative stress parameters in the blood of rats treated with paracetamol.

\section{MATERIALS AND METHODS}

\section{Chemicals}

Chemicals for this study were obtained from Sigma-Aldrich Chemie GmbH (Germany) and Merck (Darmstadt, Germany). All reagents and chemicals were of analytical grade or higher purity.

\section{Animals}


The study included male adult Wistar albino rats, 8 weeks old, weighing $210 \pm 20 \mathrm{~g}$ at the beginning of the experiment. The animals were maintained in individual plastic cages under standard laboratory conditions (temperature $22{ }^{\circ} \mathrm{C} \pm 2{ }^{\circ} \mathrm{C} ; 12 \mathrm{~h}$ light-dark cycle). The animals had unlimited access to drinking water and standard rodent laboratory diet. At the end of experimental period animals were anesthetized with ether and sacrificed by decapitation. All animal experiments were approved by the University Committee of the Ethics of Animal Experimentation.

\section{Experimental design}

After a period of adaptation for one week prior to the experiment, animals were randomly divided into three groups $(n=5$ per group $)$ and treated as follows:

Group 1: Control, treated intraperitoneally (i.p.) with isotonic saline.

Group 2: Paracetamol, treated in a dose of $100 \mathrm{mg} / \mathrm{kg} / \mathrm{day}$ i.p.

Group 3: Paracetamol + Vit C $+\beta$-glucan, treated with paracetamol $(100 \mathrm{mg} / \mathrm{kg} / \mathrm{day}$ i.p. $)+$ vitamin C (Vit C, $100 \mathrm{mg} / \mathrm{kg} /$ day i.p.) $+\beta$-glucan (1,3-1,6 $\beta$-D-glucan, $40 \mathrm{mg} / \mathrm{kg} / \mathrm{day}$ i.p.).

Treatments were carried out 3 days consecutive; the animals were anaesthetized with ether and sacrificed $24 \mathrm{~h}$ after the last administration.

\section{Blood sampling}

Blood samples were collected between 8 and 10 a.m. to avoid circadian rhythm induced changes. The blood samples were collected in tubes using K-EDTA as anticoagulant for hematological analysis and in tubes without anticoagulants for the other analysis. Haematological and biochemical parameters were measured on the day of sacrifice.

\section{Haematological methods}

EDTA-added whole blood samples were used for haematological examination. Haematological parameters like number of red blood cell (RBC), white blood cell (WBC), platelets (PLT), haemoglobin (Hb) concentration and haematocrit $(\mathrm{Ht})$ values were determined by standard methods on automated haematology analyzer (Horiba Medical ABX Micros 60, Japan).

\section{Biochemical methods}

Blood samples in non anticoagulant tubes were centrifuged at $4000 \mathrm{rpm}$ for $15 \mathrm{~min}$ at $+4{ }^{\circ} \mathrm{C}$, and serum was used. Measurement of biochemical parameters as serum total protein (TP), albumin, globulin and activities of serum enzymes (alanine aminotransferase (ALT), aspartate aminotransferase (AST) and lactate dehydrogenase (LDH)), as well as electrolytes were performed on an autoanalyzer (C 8000 Architect, Germany) using diagnostic colorimetric kits (Abbott laboratories).

\section{Oxidative stress parameters}

To measure oxidative stress parameters, blood samples were centrifuged at $4000 \mathrm{rpm}$ $\left(+4{ }^{\circ} \mathrm{C}\right)$ for $10 \mathrm{~min}$ and plasma was removed. Erythrocytes were washed three times with an equal volume of cold saline $(0.9 \%, \mathrm{v} / \mathrm{v})$, and $1 \mathrm{ml}$ of washed erythrocytes was lysed on ice in $3 \mathrm{ml}$ of $\mathrm{dH}_{2} \mathrm{O}(1: 3, \mathrm{v} / \mathrm{v})$ for $30 \mathrm{~min}$. The final haemolysates were divided into three parts, put into eppendorf tubes and stored at $-80{ }^{\circ} \mathrm{C}$ until assay. 
Lipid peroxides (LPO) level in haemolysate was determined using method described by Ohkawa et al. (1979) based on the reaction of lipid peroxidation products (MDAmalondialdehydes) with TBA (thiobarbituric acid reactive substances - TBARS analysis). The results were expressed in $\mu \mathrm{mol} \mathrm{MDA} / \mathrm{L}$ erythrocytes, using a molar extinction coefficient for MDA of $1.56 \times 10^{5} \mathrm{M}^{-1} \cdot \mathrm{cm}^{-1}$.

The level of reduced glutathione (GSH) was determined on the basis of GSH oxidation with DTNB (5.5'-dithiobis-2-nitrobenzoic acid) using Beutler method (1975), and the concentrations were expressed as $\mathrm{nmol} / \mathrm{g} \mathrm{Hb}$.

\section{Statistical analysis}

All the group data were statistically evaluated with SPSS/13 software. The results were expressed as mean \pm S.E.M. and analyzed by factorial analysis of variance (ANOVA) using a post hoc Bonferroni/Dunnett's multiple analysis, or by nonparametric Kruskal-Wallis test, where $p<0.05$ was considered statistically significant.

\section{RESULTS}

\section{Haematological results}

The results of haematological analysis of rats in the control and treatment groups are presented in Table 1. Results indicated that paracetamol caused a significant decrease in RBCs count, $\mathrm{Hb}$ concentration and $\mathrm{Ht}$ value, while increased WBCs count compared to the control. However, there were insignificant alterations in PLT count. Coadministration of vitamin $\mathrm{C}$ and $\beta$-glucan with paracetamol reversed these changes of haematological parameters to the values measured in control rats and diminished the toxic effects of paracetamol.

Table 1. Effects of vitamin $C$ and $\beta$-glucan on haematological parameters in blood of paracetamol-treated rats.

\begin{tabular}{|c|c|c|c|}
\hline \multirow[b]{2}{*}{ Parameters } & \multicolumn{3}{|c|}{ Experimental groups } \\
\hline & Control & Paracetamol & $\begin{array}{c}\text { Paracetamol + } \\
\text { Vit } C+\beta- \\
\text { glucan } \\
\end{array}$ \\
\hline $\operatorname{RBC}\left(10^{12} / L\right)$ & $7.34 \pm 0.31$ & $6.16 \pm 0.40^{*}$ & $6.85 \pm 0.28^{\#}$ \\
\hline $\mathrm{Hb}(\mathrm{g} / \mathrm{L})$ & $145.0 \pm 5.43$ & $131.3 \pm 3.62 *$ & $143.2 \pm 2.74^{\#}$ \\
\hline Ht $(\%)$ & $39.61 \pm 0.76$ & $35.37 \pm 0.27 *$ & $38.75 \pm 1.22^{\#}$ \\
\hline WBC $\left(10^{9} / \mathrm{L}\right)$ & $6.30 \pm 0.23$ & $9.57 \pm 0.17 *$ & $7.25 \pm 0.45^{\#}$ \\
\hline PLT $\left(10^{9} / \mathrm{L}\right)$ & $574.8 \pm 31.5$ & $637.2 \pm 29.7$ & $568.7 \pm 26.8^{\#}$ \\
\hline
\end{tabular}

Vit C: vitamin C; $\beta$-glucan: 1,3-1,6 $\beta$-D-glucan; RBC: red blood cell;

Hb: haemoglobin; Ht: haematocrit; WBC: white blood cell; PLT: platelets.

Values are expressed as means \pm SEM, $(n=5$ animals $)$.

${ }^{*} p<0.05$, significantly different from control;

$\# p<0.05$, significantly different from paracetamol group. 


\section{Biochemical parameters}

Table 2 and Table 3 shows effects of treatment on biochemical parameters. Treatment with paracetamol resulted in a significant decrease in serum total protein (TP), albumin and globulin, while caused a significant increase ALT, AST and LDH activities compared to the control (Table 2). Coadministration of vitamin $C$ and $\beta$-glucan with paracetamol reversed paracetamol-induced alterations in these biochemical parameters.

Table 2. Effects of vitamin $\mathrm{C}$ and $\beta$-glucan on biochemical parameters in serum of paracetamol-treated rats.

\begin{tabular}{lccc}
\hline & \multicolumn{3}{c}{ Experimental groups } \\
\cline { 2 - 4 } Parameters & Control & Paracetamol & $\begin{array}{c}\text { Paracetamol + } \\
\text { Vit C }+\boldsymbol{\beta} \text { - } \\
\text { glucan }\end{array}$ \\
\hline TP (g/L) & $64.2 \pm 1.4$ & $59.0 \pm 2.1^{*}$ & $62.3 \pm 1.6$ \\
Albumin (g/L) & $13.7 \pm 0.8$ & $12.3 \pm 0.4^{*}$ & $13.4 \pm 0.6$ \\
Globulin (g/L) & $50.5 \pm 1.6$ & $46.7 \pm 2.1^{*}$ & $48.9 \pm 1.5$ \\
ALT (IU/L) & $47.5 \pm 2.1$ & $62.3 \pm 1.9^{*}$ & $49.4 \pm 2.8^{\#}$ \\
AST (IU/L) & $148.2 \pm 5.8$ & $178.3 \pm 6.4^{*}$ & $143.7 \pm 4.6^{\#}$ \\
LDH (IU/L) & $565.8 \pm 24.6$ & $898.3 \pm 65.2^{*}$ & $734.6 \pm 39.3^{\#}$ \\
\hline
\end{tabular}

Vit C: vitamin C; $\beta$-glucan: 1,3-1,6 $\beta$-D-glucan; TP: total protein; ALT: alanine aminotransferase; AST: aspartate aminotransferase; LDH: lactate dehidrogenase. Values are expressed as means \pm SEM, ( $n=5$ animals).

$* p<0.05$, significantly different from control;

$\# p<0.05$, significantly different from paracetamol group.

Table 3. Effects of vitamin $C$ and $\beta$-glucan on electrolytes in serum of paracetamol-treated rats.

\begin{tabular}{lccc}
\hline \multirow{2}{*}{ Parameters } & \multicolumn{3}{c}{ Experimental groups } \\
\cline { 2 - 4 } & Control & Paracetamol & $\begin{array}{c}\text { Paracetamol + } \\
\text { Vit } \mathbf{C}+\boldsymbol{\beta}- \\
\text { glucan }\end{array}$ \\
\hline $\mathbf{N a}^{+}(\mathbf{m m o l} / \mathbf{L})$ & $158.0 \pm 2.8$ & $135.2 \pm 2.4^{*}$ & $174.1 \pm 5.7^{\#}$ \\
\hline $\mathbf{K}^{+}(\mathbf{m m o l} / \mathbf{L})$ & $7.5 \pm 0.3$ & $5.3 \pm 0.2^{*}$ & $6.5 \pm 0.8^{*}$ \\
\hline $\mathbf{C a}^{2+}(\mathbf{m m o l} / \mathbf{L})$ & $5.4 \pm 0.3$ & $11.3 \pm 1.4^{*}$ & $8.5 \pm 0.9^{* \#}$ \\
\hline
\end{tabular}

Vit C: vitamin $C$; $\beta$-glucan: 1,3-1,6 $\beta$-D-glucan.

Values are expressed as means \pm SEM, $(n=5$ animals $)$.

${ }^{*} p<0.05$, significantly different from control;

${ }^{\#} p<0.05$, significantly different from paracetamol group. 
Data presented in Table 3 showed that treatment with paracetamol caused significant decrease in level of serum electrolytes $\mathrm{Na}^{+}$and $\mathrm{K}^{+}$and increase in $\mathrm{Ca}^{2+}$ level compared with the control. However, in rat cotreatment of vitamin $C$ and $\beta$-glucan with paracetamol $\mathrm{Na}^{+}$ level was significantly increased, while $\mathrm{Ca}^{2+}$ level was significantly decreased in serum when compared to the group exposed to paracetamol alone.

\section{Oxidative stress parameters}

The effects of treatment on oxidative stress parameters in erythrocytes of rats are shown in Figure 1. The obtained results indicated that the concentration of LPO in erythrocytes is significantly increased (Figure 1A), while the concentration of GSH significantly decreased (Figure 1B) in the group treated with paracetamol compared to control group. Coadministration of vitamin $C$ and $\beta$-glucan with paracetamol reversed paracetamolinduced alterations in these oxidative stress parameters.
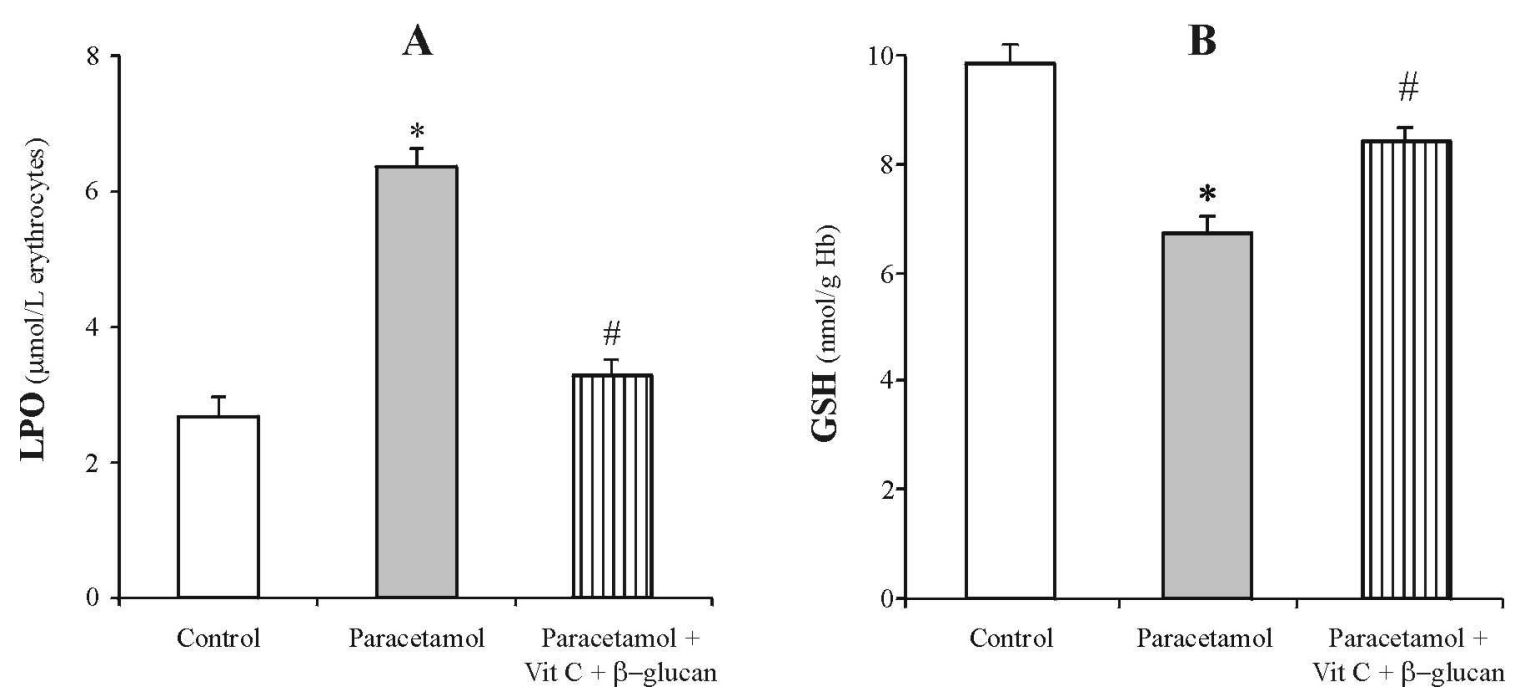

Figure 1. Effects of vitamin $C$ and $\beta$-glucan on oxidative stress parameters (LPO and GSH) in blood of paracetamol-treated rats.

Vit C: vitamin C; $\beta$-glucan: 1,3-1,6 $\beta$-D-glucan; LPO: lipid peroxidation; GSH: reduced glutathione. Values are expressed as means $\pm \mathrm{SEM},\left(n=5\right.$ animals). ${ }^{*} p<0.05$, significantly different from control; ${ }^{\#} p<0.05$, significantly different from paracetamol group.

\section{DISCUSSION}

At therapeutic doses, paracetamol is considered as a safe drug. However, when taken in overdose, it can cause hepatic necrosis, nephrotoxicity, extrahepatic lesions, and even death in experimental animals and humans (BESSEMS and VERMEULEN, 2001; HiNSON et al., 2010). In recent years there has been growing interest in understanding the role of antioxidants in management of many diseases, including clinically useful drug-induced toxicities (FAHMY and HAMDY, 2011; SINGH et al., 2011; JAESCHKE et al., 2013). This study investigated the possible protective effects of Vit $\mathrm{C}$ and $\beta$-glucan on oxidative erythrocyte damage induced in rats by high doses of paracetamol.

The results obtained in our study show that treatment with paracetamol induces changes of some haematological parameters in rats (Table 1), suggesting that the paracetamol 
induced haematotoxicity. The reduced number of $\mathrm{RBC}$, concentration $\mathrm{Hb}$ and $\mathrm{Ht}$ value was noticed, while the number of WBC increased. These findings were in agreement with other studies that found that after administration of high doses or acute poisoning with paracetamol heavy damage of the liver and kidneys was developed (MLADENOVIĆ et al., 2009; YOUSEF et al., 2010; OYEDEJI et al., 2013), leading to changes in the synthesis and function of blood cells, their increased decomposition and hemolysis. Paracetamol affects erythropoiesis and is associated with decreased production of erythrocytes in the circulation, which results in the reduced of concentration $\mathrm{Hb}, \mathrm{Ht}$ value and anaemia. Haematotoxicity that occured in animals treated with paracetamol, is characterized by the microcytosis and erythrocyte destruction. Meanwhile, the increase in WBC counts might be due to stress coupled with inflammatory changes in tissue responsible for phagocytosis of toxic substances. Due to toxic effects of paracetamol there has been an acute inflammation and leukocytosis, mainly increased number of neutrophils, which increase adhesion to endothelium and promote oxidative burst (COVER et al., 2006). Paracetamol did not significantly changed the number of PLT in comparison with the control, from which we conclude that paracetamol did not affect PLT aggregation.

In this study vitamin $C$ and $\beta$-glucan, applied in cotreatment with paracetamol, led to an increase in the number of $\mathrm{RBC}, \mathrm{Hb}$ and $\mathrm{Ht}$ compared with paracetamol treatment (Table 1). These findings showed a positive effect of these antioxidants on erythropoiesis. $\beta$-glucan induces the proliferation and differentiation of haematopoietic stem cell system (TATEISHI $e t$ $a l ., 1997)$, while vitamin $C$ provides the absorption of iron, thus providing increased synthesis of haemoglobin (HAVRLENTOVA et al., 2011). Vitamin $C$ and $\beta$-glucan in cotreatment with paracetamol significantly reduced number of WBC. TOKLU et al. (2006) showed that $\beta$-glucan in cotreatment with paracetamol shows a significant reduction of the enzyme myeloperoxidase, which is responsible for the function of neutrophils, thereby preventing the infiltration of neutrophils, and thus oxidative tissue damage caused by neutrophils. Since activation of neutrophils probably leads to the formation of reactive oxygen species (ROS), preventing the activation of neutrophils may also results in the reduction of lipid peroxidation (VĚTVIČKA et al., 2002; TOKLU et al., 2006).

Paracetamol in this research has led to a decrease in total protein (TP), albumin and globulin in serum (Table 2). A noticeable decrease in TP may be the result of reducing the number of cells responsible for protein synthesis in the liver due to necrosis (GOLDWASSER and FELDMAN, 1997). The liver is the major source of most of the serum proteins, in which the parenchymal cells are responsible for synthesis of albumin, fibrinogen and other coagulation factors and most of the $\alpha$ and $\beta$ globulins (THAPA and WALIA, 2007). Albumin is quantitatively the most important protein in the plasma. Reducing the concentration of albumin occurs mainly due to increased vascular permeability during acute inflammation and their release into intercellular spaces. A low serum albumin indicates poor liver function and so the reduction in albumin levels are generally suggestive of liver disease. Albumin binds to drugs or chemicals and facilitates their transportation (THAPA and WALIA, 2007). The observed decrease in albumin by paracetamol could be a result of a decline in the number of cells responsible for albumin synthesis in the liver through necrosis (GOLDWASSER and FELDMAN, 1997). Our study revealed that vitamin $C$ and $\beta$-glucan retained the measured proteins into its normal levels, suggesting that this treatment did not significantly affect metabolism of proteins.

After ingestion of chemicals or drugs like a paracetamol, there are many enzymes found in the serum that did not originate from the extracellular fluid. After tissue damage, some of these enzymes find their way into the serum leaking through membranes with altered permeability. Serum enzymes [aspartate aminotransferase (AST), alanine aminotransferase (ALT) and lactate dehydrogenase (LDH)] activity measurements are a valuable tool in clinical diagnosis. Measurement of these enzymes activities in tissues and body fluids can be used to 
estimate the degree of toxicity of a chemical compound on organ/tissues (YOUSEF et al., 2010).

ALT and AST are commonly used biochemical markers of hepatocellular necrosis (FRIEDMAN et al., 1996). In necrosis of hepatocytes, these enzymes pass into the blood, and therefore are considered as a sensitive index of hepatocellular damage. LDH is an enzyme found in the liver, kidneys, skeletal muscles, platelets and catalyzes the conversion of lactate to pyruvate. Increased levels of LDH in human serum reflects the degree of destruction of cells and toxic side effects in tissues which are rich in this enzyme. Our results showed that the activities of the enzymes (ALT, AST and LDH) significantly increased in animals that were treated with paracetamol, compared to the control (Table 2). These changes indicate that the paracetamol caused liver damage, disrupting the functional integrity of cell membranes, and led to the release of these enzymes in serum. These results are similar with the ones reported in the study by YANG et al. (2012) and HASSANIN et al. (2013).

Administration of vitamin $\mathrm{C}$ and $\beta$-glucan showed significant decrease activities of hepatic marker enzymes (AST, ALT and LDH), which reflects their protective effect (Table 2). Our results are in agreement with other researches (ADENEYE and OlAGUNJU, 2008; HASSANIN et al., 2013), and suggest that vitamin $C$ and $\beta$-glucan are able to preserve the functional integrity of cell membranes of hepatocytes and to prevent necrosis and „leak" of these enzymes in the bloodstream.

The results indicate that paracetamol is led to significant decrease in the concentration of $\mathrm{Na}^{+}$and $\mathrm{K}^{+}$and increase of $\mathrm{Ca}^{2+}$ in the serum compared to the control (Table 3). The reduced concentration of $\mathrm{Na}^{+}$can be a result of inhibition of the $\mathrm{Na}^{+} / \mathrm{K}^{+}$-ATP-ase. It is shown that toxic concentrations of paracetamol lead to oxidative damage and reduced flexibility of erythrocytes, increased membrane permeability and osmotic weaknesses of cells, which results in increased degradation or haemolysis of erythrocytes (YOUSEF et al., 2010). Increased $\mathrm{Ca}^{2+}$ is a result of toxic metabolite NAPQI, and leads to variety of destructive processes, which involves the destruction of cytoskeleton, activation of catabolic enzymes, phospholipases, endonucleases, and proteases, and loss of ATP production. However, in rat cotreatment of vitamin $\mathrm{C}$ and $\beta$-glucan with paracetamol $\mathrm{Na}^{+}$level was significantly increased, while $\mathrm{Ca}^{2+}$ level was significantly decreased in serum when compared to the group exposed to paracetamol alone.

Several studies have indicated that oxidative stress and lipid peroxidation (LPO) are an important factors in the development of paracetamol-associated hepatotoxicity (MLADENOVIĆ et al., 2009; YoUSEF et al., 2010). Antioxidant and anti-inflammatory agents play a crucial role against paracetamol intoxication by scavenging active oxygen and free radicals and neutralizing lipid peroxides (YOUSEF et al., 2010). Among several proposed mechanisms of protective effects of $\beta$-glucan, the major one is related to its antioxidant capacity (HAVRLENTOVA et al., 2011; UsKOKOVIĆ et al., 2013). Vitamin C is naturally occurring free radical scavenger and can protect biomembranes against peroxidative damage.

It was found that toxic paracetamol concentrations reduce deformations of erythrocytes and increase membrane permeability, cytosolic $\mathrm{Ca}^{2+}$ concentrations and osmotic fragility of cells, resulting in reduced erythrocyte survival (HINSON et al., 2010). The results of this work show that treatment with paracetamol caused a significant increase in the concentrations of LPO in the erythrocytes (Figure 1A), indicating oxidative damage of cell membranes and the occurrence of oxidative stress.

Increased LPO level after paracetamol treatment, which is in accordance with research by other authors (MLADENOVIĆ et al., 2009; DA ROSA et al., 2012), led to tissue damage and inability of antioxidant system to prevent the formation of excessive free radicals. Malondialdehyde (MDA) is one of the end-products of oxidative damage to lipids, and can react with amino groups of proteins and nucleic acids, causing even greater cell damage. 
Lipid peroxidation reduces the fluidity of biological membranes, thereby increasing the permeability to monovalent and divalent ions and inactivate the membrane enzymes. Intensive lipid peroxidation in biological membranes leads to a decrease in membrane potential, increase permeability to $\mathrm{H}^{+}$and other ions, which in the end results in spraying of the cells and release its contents (HALLIWELL and GUTTERIDGE, 2007).

Furthermore, vitamin $C$ and $\beta$-glucan treatment had significantly reduced LPO (Figure $1 \mathrm{~A})$, indicating its potential role to protect the erythrocytes by reducing lipid peroxidation, oxidative stress and haematotoxicity. Toklu et al. (2006) showed that treatment with $\beta$-glucan significantly reduces the production of MDA, which means that there has been a reduction in LPO and cell damage. Both animal (ODIGIE et al., 2007) and human studies (DoGUN and AJALA, 2005) have shown that vitamin $\mathrm{C}$ has a protective and antioxidative effect in „scavenging“ ROS. The vitamin C donates electrons to break the chain reaction of lipid peroxidation.

Reduced glutathione (GSH) is a major endogenous antioxidant which counterbalances free radical mediated damage. Decreased cellular GSH levels and capacity for GSH synthesis sensitize cells to radiation and to certain drugs (KOZER et al., 2003).

The results of this work show that paracetamol treatment induces oxidative stress and decreased GSH level in the rat erythrocytes (Figure 1B). Paracetamol toxicity in the liver is mainly interceded by the covalent binding of NAPQI, the reactive metabolite of paracetamol, to sulfhydryl groups of GSH and various proteins and their subsequent oxidation (HINSON et $a l ., 2010)$. Overproduction of free radical in alone paracetamol-intoxicated rat might have upshot the erythrocytic lipid peroxidation, and consequently increased MDA contents. This may also be implicated with diminished erythrocytic GSH contents, as to combat the over production of free radicals, erythrocytic GSH stores might have been exhausted.

However, cotreatment with vitamin $\mathrm{C}$ and $\beta$-glucan prevented the paracetamolinduced depletion of GSH (Figure 1B). The relationship between vitamin $\mathrm{C}$ and GSH is unique. Vitamin $\mathrm{C}$ reduces GSH back to the active form. Once reduced glutathione will regenerate vitamin $\mathrm{C}$ from dehydroascorbic acid (DHAA) or oxidized state. Other studies confirm the results that the application of antioxidants increases the level of intracellular reduced glutathione (TOKLU et al., 2006; HASSANIN et al., 2013). Various studies shown that vitamin $C$ and $\beta$-glucan exhibit protective effects (HAVRLENTOVA et al, 2011; VĔTVIČKA and VĚTVIČKOVA, 2012; HASSANIN et al., 2013). The aim of this study was to show the synergistic effect of these two antioxidants in coadministration with paracetamol.

\section{CONCLUSION}

In conclusion, changes in haematological and biochemical parameters, as well as changes in levels of oxidative stress markers and erythrocytes damage indicate that acute use of paracetamol may lead to development of haematotoxicity and associated disease. The findings of the present study also show that vitamin $\mathrm{C}$ and $\beta$-glucan reduces the paracetamolinduced erythrocytes damage and dysfunction by reducing the GSH depletion, oxidative stress generation and lipid peroxidation. Our results suggest that vitamin $C$ and $\beta$-glucan may be of therapeutic use in preventing the paracetamol toxicity.

\section{Acknowledgements}

This study was supported by the Ministry of Education, Science and Technological Development of Republic of Serbia, grant no. 173041. 


\section{References:}

[1] Adeneye, A.A., Olagunju, J.O. (2008): Protective effect of oral ascorbic acid (vitamin C) against acetaminophen-induced hepatic injury in rats. African J. Biomed. Res. 11: 183-90.

[2] Barja, G., López-Torres, M., Pérez-Campo, R., Rojas, C., Cadenas, S., Prat, J., PAMPLONA, R. (1994): Dietary vitamin C decreases endogenous protein oxidative damage, malondialdehyde, and lipid peroxidation and maintains fatty acid unsaturation in the guinea pig liver. Free Radical Biol. Med. 17: 105-15.

[3] Bessems, J.G., Vermeulen, N.P. (2001): Paracetamol (acetaminophen)-induced toxicity: molecular and biochemical mechanisms, analogues, and protective approaches. Rev. Toxicol. 31: 55-138.

[4] Beutler, E. (1975): Reduced glutathione (GSH). In: Beutler E, editor. Red cell metabolism, a manual of biochemical methods. New York: Grune and Straton: 112-14.

[5] CARR, A.C., FreI, B. (1999): Toward a new recommended dietary allowance for vitamin $\mathrm{C}$ based on antioxidant and health effects in humans. Am. Jour. Clin. Nutrition. 69: $1086-107$.

[6] Cover, C., Liu, J., Farhood, A., Malle, E., WaAlkes, M.P., Bajt, M.L., Jaeschke, H., Cover, C., Liu, J., Farhood, A., Malle, E., WaAlkes, M.P., Bajt, M.L., JAESCHKE, H. (2006): Pathophysiological role of the acute inflammatory response during acetaminophen hepatatoxicity. Toxicol. Appl. Pharmacol. 216: 98-107.

[7] Da Rosa, E.J.F., DA Silva, M.H., Carvalho, N.R., Bridi, J.C., DA Rocha, J.B.T., Carbajo-Pescador, S., Mauriz, J.L., González-Gallego, J., SoAres, F.A. (2012): Reduction of acute hepatic damage induced by acetaminophen after treatment with diphenyl diselenide in mice. Toxicol. Pathol. 40: 605-13.

[8] Dogun, E.S., AJALA, M.O. (2005): Ascorbic acid and alpha tocopherol antioxidant status of type 2 diabetes mellitus patients seen in Lagos. Niger Postgrad. Med. J. 12: 155-57.

[9] DRÖGE, W. (2002): Free radicals in the physiological control of cell function. Physiol Rev. 82: 47-95.

[10] FAHMY, S.R., HAMDY, S.A.H. (2011): Antioxidant effect of the Egyptian freshwater Procambarus clarkii extract in rat liver and erythrocytes. African J. Pharm. Pharmacol. 5: $776-85$.

[11] Friedman, L.S., Martin, P., MunOz, S.J. (1996): Liver function tests and the objective evaluation of the patient with liver disease. In: Zakin D, Boyer TD, eds. Hepatology: a textbook of liver disease. Philadelphia: WB Saunders: 791-833.

[12] GoldWASSER, P., FELDMAN, J. (1997): Association of serum albumin and mortality risk. J. Clin. Epidemiol. 50: 693-703.

[13] Hassanin, K.M.A, HASHEM, K.S., AbDEl-Kawi, S.H. (2013): Hepatoprotective effects of vitamin $\mathrm{C}$ and micronized vitamin $\mathrm{C}$ against paracetamol induced hepatotoxicity in rats: a comparative study. Int. J. Biochem. Biotechnol. 2: 474-483. 
[14] Havrlentova, M., Petrulakova, Z., Burgarova, A., Gago, F., Hlinkova, A., ŠTURDIK, E. (2011): Cereal beta-glucans and their significance for the preparation of functional foods - a review. Czech J. Food. Sci. 29: 1-14.

[15] Halliwell, B., GutTeridge, J.M.C. (2007): Oxygen is a toxic gas - an introduction to oxygen toxicity and reactive species. In: Halliwell, B., GuTTERIDGE, J.M.C. (eds.) Free Radicals in Biology and Medicine. Oxford: Oxford University Press: 1-29.

[16] Hinson, J.A., Roberts, D.W., James, L.P. (2010): Mechanisms of acetaminopheninduced liver necrosis. Handbook of Experimental Pharmacology 196: 369-405.

[17] JaeschKe, H., Williams, C.D., Mcgill, M.R, Xie Y., Ramachandran, A. (2013): Models of drug-induced liver injury for evaluation of phytotherapeutics and other natural products. Food Chem. Toxicol. 55: 279-89.

[18] Kozer, E., Evans S., Barr, J., Soriano, I., Bulkowstein, M., Petrov, I., Chen-Levi, Z., BARZILAY, B., BERKOVITCH, M. (2003): Glutathione, glutathione-dependent enzymes and antioxidant status in erythrocytes from children treated with high-dose paracetamol. British J. Clin. Pharmacol. 55: 234-40.

[19] Mladenović, D., Radosavljević, T., Ninković, M., Vučević, D., JeŠić-VukićEvić, R., TODOROVIĆ, V. (2009): Liver antioxidant capacity in the early phase of acute paracetamol-induced liver injury in mice. Food Chem Toxicol. 47: 866-70.

[20] Odigie, I.P., OKPOKO, F.B., OJOBOR, P.D. (2007): Antioxidant effects of vitamin C and $\mathrm{E}$ on phenylhydrazine-induced haemolysis in sprague dawley rats: evidence for a better protection by vitamin E. Niger Postgrad. Med. J. 14: 1-7.

[21] OyedejI, K.O., Bolarinwa, A.F., OJeniRan, S.S. (2013): Effect of paracetamol (acetaminophen) on haematological and reproductive parameters in male albino rats. Res. J. Pharmacol. 7: 21-25.

[22] Singh, S., Singh, S.K., Kumar, M., Chandra, K., Singh, R. (2011): Ameliorative potential of quercetin against paracetamol-induced oxidative stress in mice blood. Toxicol. Int. 18: 140-45.

[23] TAteishi, T., Ohno, N., AdAchi, Y., Yadomae, T. (1997): Increases in hematopoietic responses caused by beta-glucans in mice. Biosci. Biotechnol. Biochem.. 61:1548-53.

[24] ThapA, B.R, Walia, A. (2007): Liver function tests and their interpretation. Indian J. Pediatr. 74: 663-71.

[25] ToKlu, H.Z., ŞEhIRli, A.Ö, VelioĞLu-ÖĞÜNÇ, A., ÇETINEL, Ş., ŞENER, Ş. (2006): Acetaminophen-induced toxicity is prevented by $\beta$-D-glucan treatment in mice. Eur. $J$. Pharm. 543: 133-40.

[26] Uskoković, A., Mihailović, M., Dinić, S., Arambašić, J.J., Grdović, N., Marković, J., Poznanović, G., Vidaković, M. (2013): Administration of a $\beta$-glucan-enriched extract activates beneficial hepatic antioxidant and anti-inflammatory mechanisms in streptozotocin-induced diabetic rats. Journal of Functional Foods 5: 1966-74.

[27] VětVičKa, V., Terayama, K., Mandeville, R., Brousseau, P., Kournikakis, B., Ostroff, G. (2002): Beta-glucan as immunomodulator. J. American. Nutraceut. Ass. 2 : $16-20$.

[28] VĚTVIČKA V., VĚTVIČKOVA, J. (2012): Glucan-resveratrol-vitamin C combination offers protection against toxic agents. Toxins 4: 1301-8. 
[29] WILSON, J.X. (2002): The physiological role of dehydroascorbic acid. FEBS Lett. 527: 5-9.

[30] Yang X., Greenhaw J., Ali A., Shi Q., Roberts D.W., Hinson J.A., Roberts, D.W., Hinson, J.A., Muskhelishvili, L., Beger, R., Pence, L.M., Ando, Y., Sun, J., DAvis, K., SALMINEN, W.F. (2012): Changes in mouse liver protein glutathionylation after acetaminophen exposure. J. Pharmacol. Exp. Ther. 340: 360-8.

[31] Yousef, M.I., Omar, S.A.M., El-Guendi, M.I., AbDelmegid, L.A. (2010): Potential protective effects of quercetin and curcumin on paracetamol-induced histological changes, oxidative stress, impaired liver and kidney functions and haematotoxicity in rat. Food Chem. Toxicol. 48: 3246-61. 